\title{
Sketches Toward an Ontology of Non- Dwelling: Mara Salvatrucha 13, Radical Homelessness, and Postglobality
}

Anthony Ramos

Journal of French and Francophone Philosophy - Revue de la philosophie française et de langue française, Vol XXV, No 1 (2017) 61-85.

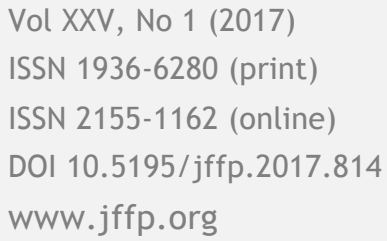

\section{(c)) EY-NO-ND}

This work is licensed under a Creative Commons Attribution-Noncommercial-No Derivative Works 3.0 United States License.

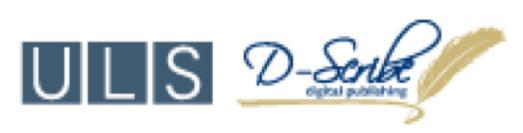

This journal is operated by the University Library System of the University of Pittsburgh as part of its D-Scribe Digital Publishing Program, and is co-sponsored by the University of Pittsburgh Press 


\title{
Sketches Toward an Ontology of Non-Dwelling
}

\author{
Mara Salvatrucha 13, Radical Homelessness, and \\ Postglobality
}

\author{
Anthony Ramos \\ City University of New York
}

The California state legislature passed the California Street Terrorism Enforcement and Prevention Act (STEP), in 1988, allowing courts to "enhance" the sentences of offenders who are proven to "promote, further, or assist in any criminal conduct by gang members." ${ }^{1}$ The law passed, in large part, as a measure address the fear of the hyper-violent Black/Latino Other, couched within its terms were the fears associated with the "crack epidemic" and inner-city crime. These discourses had provided an invaluable warrant for legislators keen on bundling together criminality, policing, and incarceration that we now understand as foundational to the emergence of mass-incarceration. Jumping to April of 2016, the Salvadoran government has passed strikingly similar legislation, but it centers on reclassifying gangassociated crimes as terroristic. These laws have in essence reclassified gang affiliation as terroristic activity. They have, as well, been enacted in the midst of panics about gang violence and the low-level warfare, between gangs and the Salvadoran state, breaking out on city streets. The adoption of US-style anti-gang approaches by the Salvadoran government is not new. Back in 2003, when the right-wing Allianza Republicana Nacionalista [Nationalist Republican Alliance, ARENA] was in power, a set of mano dura ["iron fist"] were passed with the aim of curbing gang activity through zero-tolerance and tough-on-crime measures. As well, these policies granted more leeway in the use of force for police and afforded more discretion to law enforcement to target and arrest suspected gang members, especially those from Mara Salvatrucha 13 (MS-13) and Barrio 18. Mano dura policies built, arguably, the foundation for has been an outright urban war between gangs and the Salvadoran state. The reason for considering these two seeming distinct political maneuvers in conjunction is to begin asking why have anti-gang discourses such an effective political tool, even though the policies drawn

Journal of French and Francophone Philosophy | Revue de la philosophie française et de langue française Vol XXV, No 1 (2017) | www.jffp.org | DOI 10.5195/jffp.2017.814 
from them have proven ineffective and counter-productive? The similarities between anti-gang legislation in Los Angeles and El Salvador are certainly tied to processes of political exchange as well to the transnational ties between each locale. However, I want to consider to what extent anti-gang legislation is a symptom of a contradiction more deeply embedded within the currents of globalization.

On one level, we can frame the adoption of US-style zero-tolerance policies and anti-gang tactics as examples of the flexibility of neoliberal globalization, and its juridical strategies and policing tactics, embedded in a "society of control and biopower." ${ }^{2}$ How they extend a neoliberal governmentality, itself produced by the calculations of states seeking "to maximize profitable connections with global capital through a checkerboard of political processes of graduated rule." ${ }^{3}$ States that aim to seize security at the expense of the forbidden and excluded-labor forms, social actions, or ideologies). From this vantage, we, as scholars, have traced the strategies and tactics of power in rendering visible the array of cosmopolitan, political, and economic subjectivities elicited by neoliberal globalization and how they facilitate the production and reproduction of subalternity and oppression, associated with the accumulation of wealth. However, I want to use this essay to explore the gang phenomena from a different vantage. I want to suggest, first, that gangs occupy a peculiar subject position that has made it difficult to consider the gang phenomena ontologically.

Gangs, I will contend below, sit outside the mappings of power relations and social formations that constitute our analysis of the biopolitical field and capitalist society. That is because, how we consider social formations, like the MS-13, is always already tied to a notion of humanity in which gangs, as Agamben might note, are discursively included in their exclusion. What a gang is, ontologically speaking, has been given short shrift. The disregard for what gang means leaves us incapable of grasping the troubling nature of gangs. I mean, to say, as to the essence of the language through which certain human activity comes to known as gang activity. However, their inclusion by exclusion, evident in STEP's language, gives us a clue to begin exploring why.

The ostensible aims of STEP is to provide effective measures to punish those people whose behaviors "threaten and terrorize peaceful citizens." Per the law, "these criminal street gang activities, both individually and collectively, present a clear and present danger" to the state. ${ }^{4}$ The laws, on the one hand, made gang activity a substantive crime-that is, a person is classified as criminal for merely obtaining gang affiliation - and subjects gang members to enhanced sentences and increased policing. On the other hand, the language concerning what exactly constitutes a gang remains vague and left to judicial discretion. ${ }^{5}$ The fact that such laws have disproportionately affected poor Black/Latino communities reveals their actual function. A reality especially troubling since the purpose of these laws is the eradication

Journal of French and Francophone Philosophy | Revue de la philosophie française et de langue française Vol XXV, No 1 (2017) | http://www.jffp.org | DOI 10.5195/jffp.2017.814 
of the social element we call gangs. Furthermore, this means STEP is a law with existential concern: that is, the non-existence of gangs and its members. The law makes clear that gangs should not have a place within the state, its cities, or communities. Gangs having an ability to assemble and, in Heideggerian terms, dwell within a community is in-and-of-itself a threat to the state. Thus, what STEP has codified into law is the non-dwelling status of anyone inscribed as a gang member, while leaving open the question of what exactly constitutes gang activity or formation.

Moreover, by collapsing gang activity into terrorism, STEP combines fears of the Other and the arbitrariness of gang, or terrorist, classification in a manner that justifies the extension of globalizing forms of social control. The shift to the penal state, and the "colonization of the welfare sector by the panoptic and punitive logic," ${ }^{\prime \prime}$ is possible precisely because the legibility of gangs as evildoers has cajoled governments, and us, into accepting intensive forms of incarceration, surveillance, and workfare as legitimate state interventions. An echo of this mentality has reverberated in the Salvadorian context where mano dura policies have legitimized the incarceration and death of people associated with gang activity. Gangs are the bogeyman of modern urbanity. Their presence triggers waves of panic inflamed by media frenzies that amplify, rather than clarify their actual threat. Still, the reality of the situation has made it difficult to understand the significance of gang formation, especially problematic given the breadth of their existence. What is needed is an account of what gangs are, which begins with questioning the foundations on which the discursivities about gang violence and terrorism have, I argue, constituted a controlling logic that upholds the status quo through the construction of gangs as the problem, a problem people.

La Mara Salvatrucha 13 is an especially relevant prism for understanding what gangs are. MS-13 formed during the deindustrialization of Los Angeles in the mid-1980s. They are the children of Salvadoreño refugees who came to the area fleeing El Salvador's bloody civil war. ${ }^{11}$ They are most noted for their members' tendency for covering their bodies with tattoos of devils, lovers, children, and the MS-13 insignia. Originally formed to help recent immigrants survive within Los Angeles' gang territories. The MS-13 is now a transnational phenomenon largely due to the deportation tactics of US law enforcement. Their presence has caused panics in cities throughout the US and Central America. Due to their association with extreme violence and organized crime, government agencies consider MS-13 a grave threat to national security and urban life. Notwithstanding, the MS-13 provide a particularly evocative case since the connective tissue of the neoliberal world is most evident in the traumatic experiences of those for who its world exploits. They are the postglobal subjects vomited ${ }^{12}$ from the neoliberal world, who become visible in "those moments when globalization as a hegemonic discourse stumbles, when it experiences a crisis or setback."13 The MS-13 are among the people the neoliberal world has been designed to exploit, or simply

Journal of French and Francophone Philosophy | Revue de la philosophie française et de langue française Vol XXV, No 1 (2017) | http://www.jffp.org | DOI 10.5195/jffp.2017.814 
disregard. Their narrative provides insight into the ontology of radically homeless (post)global subjects.

In this essay I propose a set of questions about the MS-13, which are concern as to what is its gang-ness. I will consider why the existence has been crucial to ideologies of criminality, which through constant panics have created their "own momentum for measures of 'more than usual control'."18 In a parallel register, I want to consider the peculiarity of their existence and how they are radically homeless. That is, how are gangs integral to the security apparatuses associated with the neoliberal state and how they rely on discourses emerging from the ontology of neoliberalism that has, if not required, relied on a particular set of people being ontologically abject, included by their exclusion. And lastly, I want to consider the implications of this radical homelessness, and what does it mean to not-dwell, to not have a home in the language in which we imagine and construct our social worlds.

The remainder of this essay presents a series of sketches examining the radical homelessness of MS-13. I will begin with a seemingly tangential subject, the way in which Karl Marx understood the knave, a deviant figure that did not have a place in his mapping of class subjectivities. Next, I outline the political economy of Los Angeles's urban formation, to elucidate how it's urban planning explicitly elicits the dwelling of certain people while disregarding others. Then, I will explore how the MS-13 are denied dwelling within Los Angeles, through anti-gang initiatives and policing strategies that occlude the power relations shaping their neighborhoods. The final sketches will explore the implications of non-dwelling on a transnational scale. The task here is not to define the political structure of the MS-13. Rather, I seek to reassemble the entanglement of social relations and power that have come to reify their radical homeless while exploring the consequences of their nondwelling.

\section{Revisiting Marx’s ‘Knavish’ Lumpen}

What exactly Karl Marx meant by "lumpen" remains largely enigmatic. Although, according to Thoburn's reading, Marx's lumpenproletariat is "a category which is marked by its externality to capitalist social relations and its inability to engage with the potential becoming of history." 20 This "externality" set the lumpen apart from the proletariat whose labor Marx associated with the productive forces of History-either as labor bent to the wheels of capital or labor realizing its agency in class struggle. Thinking through the externalization of the lumpen, in Marx's grammar, provides a means to trace his thinking on the character of labor caught in what he called the "reserve army." The surplus labor pools created by the vacillation between labor and idleness, he argued, that was required by capital.

Journal of French and Francophone Philosophy | Revue de la philosophie française et de langue française Vol XXV, No 1 (2017) | http://www.jffp.org | DOI 10.5195/jffp.2017.814 
During the social transformations in $19^{\text {th }}$ century Europe, much concern surrounded the character of these masses, as Le Bon's study on the crowd attests: ".... at the bottom of the social ladder the system creates an army of proletarians discontented with their lot and always ready to revolt, while at the summit it brings into being a frivolous bourgeoisie, at once sceptical and credulous, having a superstitious confidence in the State [emphasis mine]." 21 In the 18th Brumaire, we similarly find Marx engaged in the question of the masses. His concern was discerning the interconnection between surplus value and surplus labor, which had something to do with the distinction between the honest work of proletariats and the easily inveigled anarchic and narcissistic energies of the lumpen. Hence the curious contrast Marx made between the proletariat and lumpen:

vagabonds, discharged soldiers, discharged jailbirds, escaped galley slaves, swindlers, mountebanks, lazzaroni, pickpockets, tricksters, gamblers, maquereaux [pimps], brothel keepers, porters, literati, organ grinders, ragpickers, knife grinders, tinkers, beggars-in short, the whole indefinite, disintegrated mass, thrown hither and thither... this scum, offal, refuse of all classes. ${ }^{22}$

The lumpenproletariat was, in short, déclassé, a lot of miscreants, standing outside and against the proletariat class, and all its revolutionary potentiality and determinacy. In this way, as Thoburn argues, lumpen, in Marx's grammar, is best translated as "knave." Shakespeare's usage of knave from King Lear serves us here:

A knave; a rascal; an eater of broken meats; a base, proud, shallow, beggarly, three-suited, hundred-pound, filthy, worsted-stocking knave; a lily-livered, action-taking knave, a whoreson, glass-gazing, super-serviceable finical rogue; one-trunk-inheriting slave; one that wouldst be a bawd, in way of good service, and art nothing but the composition of a knave, beggar, coward, pandar, and the son and heir of a mongrel bitch: one whom I will beat into clamorous whining, if thou deniest the least syllable of thy addition. ${ }^{23}$

There is an eerie resemblance between Kent's admonishment of Oswald and Marx's chiding of the lumpen. I argue the resemblance speaks to, on the one hand, the presence of the "included excluded" figure that Agamben has noted exists in the structure of Western politics. Though, there is also a question about the value attached to the structurally included excluded figure which is not accounted for in Agamben's tracing of the homo sacer that I must consider when acknowledging the knave. The lumpen are, in Marx's own words, not simply a byproduct of capital processes, they are a site where surplus labor and the ills of society congeal. The consideration of this double bind is key for understanding how the lumpen figure was both considered to lack historical import, yet their very existence stood against, Marx argued, the interests of the proletariat. How, in Marx's grammar, the lumpen function to demarcate

Journal of French and Francophone Philosophy | Revue de la philosophie française et de langue française Vol XXV, No 1 (2017) | http://www.jffp.org | DOI 10.5195/jffp.2017.814 
the conceptual boundary of political economy, but as well how the lumpen functioned as sign-vehicles through which the moral economy of the author had is inscribed into the text. I am not simply suggesting Shakespeare's knave, of questionable morals and little societal import, has its echo in Marx's history of the lumpen in the second French Revolution, but that we need to consider how the lumpen figure shaped his theoretical framework.

In The Grundrisse, we again find Marx writing about the lumpen and the dishonest work of "the harlot and Pope there is [sic] a mass of such rabble. But the honest and 'working' lumpenproletariat belongs here as well; e.g. the great mob of porters etc. who render service in seaport cities etc." 24 And in Capital, the lumpen are "the lowest sediment of the relative surplus population" that "dwells in the sphere of pauperism. Apart from vagabonds, criminals, prostitutes, in short the actual lumpenproletariat." 25 Though lumpen may stand alongside honest workers in not having work, they are distinct in embodying an ethical and moral depravity that Marx finds particularly abhorrent. In each instance, the lumpen stands in as a site of difference, a particularly repugnant one.

Thus, the lumpen sticks out because of the social and moral values Marx attaches to their figuration. They are an entity, in his theories, to be feared and detested for their dishonesty, subversive aims, and comfort in depravity. This knavish element within the surplus labor pools can play no role-literally, has no place - in the struggle to transcend capital. And yet the lumpen are very much present throughout his writings on capital. ${ }^{26}$ Moreover, Marx's lumpenknave indexes - rather than destabilizes - a moral economy that underwrote many of the ideological foundations of the capitalist society he sought to critique. As I have above alluded, Marx does not fully theorize ${ }^{27}$ how normative social orders within a capitalist society produce deviant subjects. Rather, "the dialectic" was shaped by Marx's investments in a notion of humanity that defined itself through language which parsed-out the distorted, illicit, and depraved bodies understood as unfit for the proper working classes. It is a language that seeks transcendence but remains beholden to the moral economy of its author. Thus, mobilizing Marxian grammar is difficult when it is lumpen, so to say, who must be brought to the foreground of our understanding.

A Marxian framework is insufficient for understanding a social phenomenon like gangs. The manner, in which, Marx defines the proletariat both in its (1) class difference from bourgeoisie and capitalists but also by its (2) ethical/moral superiority to the knave can be depoliticizing and distorting. Such a framework, in which a knavish figure remains-included by its exclusion-elides an analysis of the interrelationships between moral economy, political economy, and juridico-political strategies and how they actively target certain elements within a society. And, perhaps, how social norms and imperatives are articulated on the backs of social constructs which parallel the figuration of the knavish lumpen.

Journal of French and Francophone Philosophy | Revue de la philosophie française et de langue française Vol XXV, No 1 (2017) | http://www.jffp.org | DOI 10.5195/jffp.2017.814 
Whether we refer to "lumpen" as knavish or criminal, what I want to suggest here is that we may not be sufficiently considering the agency of those whose existence challenges the parameters of what we implicitly understand as the activity proper to human agency. Marx diverged from classical economists, of his time, yet he could not escape their moral economy. Instead, Marx's views in many ways parallel popular Victorian thinking on deviancy and the "unrespectable poor." 29 How the poor and indigent are constructed as equally repulsive and immoral, in respect to polite society and, in Marx's case, even the radical left. They remain very much there, discursively and materially.

Marxian grammar has provided a common language for understanding the political economy of capitalism; how surplus-value and accumulation shape socioeconomic conditions and produces exploitative class relations that drive its mad scramble for profit. However, deviance is often difficult to grasp in discussions of political economy, precisely because the deviant resides on the threshold of the humanity implicit in how we speak about politics and economy. I have begun here to destabilize our grammar to sensitize us to the ontological homelessness often inscribed in our analysis of those who we find morally repulsive. Thus, Marx's méconnaissance provides a point of departure, not of foreclosure.

\section{Dwelling, or not, in Los Angeles}

Los Angeles is a global city. In general, global cities are where the contradictions of the neoliberal political economy and utopian dreamscape become manifest and visible. They are the dynamic nodal points of globalization processes that converge to transform the urban landscape to accommodate changes in labor, markets, and (im)migration. ${ }^{31}$ After WWII, cities such as L.A. sought to capture well-defined labor forces and highlycentralized industrial sectors associated with Fordist industrialism. ${ }^{32}$ Housing, in parallel, took the form of "dumb sprawl and senile suburbanization," as workers sought to grab their piece of the American pie. ${ }^{33}$ In L.A., this meant green lawns, swimming pools, and air-conditioned bungalows on top the sands of a desert basin. The Fordist city promoted "mass production, mass consumption, mass suburbanization, and...[drew] together big capital...large national labor unions, and big government." 34 This period would end with the advent of neoliberal socio-economic restructurings first implemented by the Reagan administration.

In the wake of deindustrialization, factories dispersed and decentralized, capital attached itself to floating global currencies, and vacancies in the job market paralleled vacant lots where factories once hummed with activity. The "spatial fix" 35 that had worked, as Harvey argued, for the Fordist economy had to be reconfigured to capture new labor forms and the emerging FIRE sectors. During this period Los Angeles refashioned

Journal of French and Francophone Philosophy | Revue de la philosophie française et de langue française Vol XXV, No 1 (2017) | http://www.jffp.org | DOI 10.5195/jffp.2017.814 
itself into a financial hub of geographically-dispersed production lines and global capital flows - what Sassen marks as the defining features of global cities. $^{37}$ What was witnessed in Los Angeles was a twofold movement: the dispersal of industrial/manufacturing occurring against the grain of capital consolidation into the city. These interrelated and interconnected processes have significantly reshaped the city's urban landscape, and the lived experiences of its denizens.

The above outline explains a few of the processes shaping the politics and economy of Los Angeles. It provides a map on which I situate my analysis of the MS-13 gang formation. And typically, this has been the framework for explanations focused on bringing into relief how gang formations emerge from the interstices of the city that capital investment has abandoned, or how criminal organizations formed in response to state repression, or how socialization processes associated with economic dispossession shape antisocial and violent behaviors. However, the purpose of this essay is to consider the ontological status of MS-13, specifically how their figuration in schemes of political economy often leave the question of what gang means, in its essence, and what it signifies, disregarded. I instead reconsider how we first acknowledge "gang" heuristically. Before we begin, we will need to switch orientations, here, by changing both our vantage point and theoretical framework. Such shifts can be disorienting. Thus, I will begin this reconsideration with the conceptual map provided us by Martin Heidegger since it affords a manner for thinking through the peculiarity of a gang's ontological status. A sketch of key theoretical maneuvers and heuristics employed by Heidegger will suffice to provide us equal footing from which to reconsider gangs, or as Heidegger might quip gang-ness.

The essence of Being was integral to Martin Heidegger's writings on the metaphysics of philosophical humanism. Heidegger sought to understand the foundations of what it meant to be, which he argued interconnected with what we signify when deploying Being in our language. He argued that Being had been insufficiently considered in philosophy since the notion of action had only been considered in the narrow terms of means and ends. He, rather, understood action as an unfolding of something into the fullness of its Being. In other words, to be has much to do with language, itself always already a mode of thinking, and through articulation thinking qua language brings Being into existence. Heidegger was after all critiquing how philosophical humanism had unquestionably accepted language as the means to objectify and dominate non-human beings, those entities lacking human subjectivity. But what does this have to do with gangs? Well, if we consider the essence of language to be the unfolding of, say, the human into the fullness of its humanitas, then it matters as to what is considered the threshold between humanitas and the inhuman. Furthermore, the parameters where this threshold exists in our language - the above discussion on Marx's knavish lumpen, is one such tracing-must be considered since language is, as well,

Journal of French and Francophone Philosophy | Revue de la philosophie française et de langue française Vol XXV, No 1 (2017) | http://www.jffp.org | DOI 10.5195/jffp.2017.814 
moored to the materiality of its Being. This essay is not a practice in radical relativism, in which I neglect the very real violence and tragedy associated with gang activity. However, it is a questioning of how, perhaps, a gang member's humanity comes into question-because of those very real associations - in ways that the humanity of a soldier fighting in the name of a nation-state does not. And it is a line of questioning pushing us to shift our focus towards the interrelationship between what is constructed as inhuman and the materiality of such language.

Heidegger provides us a manner in which to approach this question, brought forth by the essence of language, in his appreciation for the distinction between building and dwelling. For him, the ontological difference between various modes of being and Being, as that which is, could be understood regarding dwelling - in its distinction from and interrelation with building. For instance, if we say human subjectivity emanates from relations (to others, things, and the world), then what is this language (about human subjectivity) allowing us to consider with ease. How is it that humans come to think of themselves as humans, in the first place; and how is this related to the concept of humanness which dwells in the language from which the human emergeS. A dwelling, as such, is a gathering place, not in a geographical sense but as a somewhere in which a certain unity exists. It is a place where say an object or horizon stands out as having a distinct form. Moreover, grasping the nature of dwelling also requires an understanding of building. They are interrelated activities, to build is to obtain dwelling.

Human geographers and urban designers have often mobilized Heidegger's concept of building-as-dwelling to conceive of spatiality as an emergent phenomenon. Space does not exist a priori to the subject, but rather we can use the notion of building-as-dwelling to name "the inflection of space, the twisting and crisscrossing of interiority and exteriority from which both these horizons gain their sense." 39 Like spatiality, language does not sit a priori to the subject but rather facilitates its unfolding. It is the rubric by which our understanding of the world unfolds at the same time as facilitating our ability to dwell; "language is the house of being." 40 Language is a gathering from which we, as humans, stick out from all other beings. In a more straightforward, we may then say, the humanist project within the sciences, and its associated language is an edifice in which and from which a particular conception of human-ness is articulated. Such an understanding becomes vitally important if we begin to consider the implications for those whose existence is considered anti-thetical to humanity, like the knave, lumpen, and also the gang. Once again, we come to this question as to the parameters of this sticking out, but from the vantage point of understanding its entanglement with dwelling-as-building.

However, I must depart from Heidegger's insistence on grasping a singular ontological unity, an Ontology if you will. I do so by focusing on the social dimension of building, because we build not alone, but socially. Edifices

Journal of French and Francophone Philosophy | Revue de la philosophie française et de langue française Vol XXV, No 1 (2017) | http://www.jffp.org | DOI 10.5195/jffp.2017.814 
are always social structures and inhabit a social field, and they facilitate dwelling socially and politically. Language-as-edifice then becomes a question of language as social edifice. In this way, difference, conflict, and power will come into play when we discuss dwelling. Moreover, thinking of building as social edifices-of the structures, institutions, and formations through which the social world is experienced - provides a glimpse into how the political and moral economies of our social world are bound ontologically.

More concretely, I want to finish this section by reconsidering global cities as complexes of social edifices. That is, I want to consider how discursive formations attached to processes of globalization, urban restructuring, and local politics inform the degree to which certain people dwell in Los Angeles, while the dwelling of others is disregarded or actively foreclosed. This will mean accounting for the uneven spatiality of dwelling. How some are economically, politically, and spatially afforded dwelling. And how dwelling or non-dwelling is entangled with the moral economy and the threshold it inscribes.

The ideologies of 'creative cities' and 'smart growth' have been crucial components of Los Angeles' emergence as a global city. From applying data technologies for optimal traffic flows ${ }^{43}$ to mixed-use developments promoting sustainable communities, ${ }^{44}$ officials are building a "smarter" city to fit the new economy. L.A. is leveraging information technologies inside government agencies, through tax incentives and crowdsourcing. In conjunction with becoming "smart," L.A. is also rebranding itself to attract and cater to the needs of the creative class and global citizens. Through subtle adverts, "Discover Los Angeles" promotes a vision of this new urbanism, which promises the luxuries of living in a denser urban area. ${ }^{45}$ Politicians and urban planners are pushing to densify neighborhoods around economic centers, pocketing L.A.'s polycentric layout. Masked, however, are the processes of gentrification that have become the new "global urban strategy" aiding the rise and restructurings of globalizing cities. ${ }^{46}$

Notwithstanding, what may be novel about the creative and smart city ideologies are the ways "they constitute new objects of governance and new stakes in interurban competition." 47 Gentrifiers benefit from a city that wants to connect creative people with the tech and culture industries of the creative economy. ${ }^{48}$ Bohemians and yuppies are looking for cities to actively indulge them by redeveloping urban spaces for the creative class, often located in former industrial wastelands where cheap properties are easily transformed into edgy luxury housing, art galleries or artist collectives. On the outskirts of the city, the gated communities connected by concrete arteries allowing its denizens to visit these creative spaces, cultivated by the new urban dwellers, where they can buy from artisan boutiques, visit avant-garde galleries, or take in the newest food-truck trend. All made possible because the city of Los Angeles invests in their being able to dwell there. L.A. does so to remain competitive with other like-minded cities catering to the desires of a new elite

Journal of French and Francophone Philosophy | Revue de la philosophie française et de langue française Vol XXV, No 1 (2017) | http://www.jffp.org | DOI 10.5195/jffp.2017.814 
class within the service sector, whose desire for creative and authentic urban spaces is shaping urban planning and development in ways the Fordist city did not require. It is a process by which economic transformations have produced new subjects (e.g., creatives, bohemians, global citizens) who are pushing the city to re-build itself in a way that makes them feel at home, even as it must contend with the demands of the global economy.

The city of Los Angeles is also inhabited by a plethora of immigrants from around the world, particularly from Central America. Many come from the surplus populations uprooted from their homes by violent conflicts associated with global economic shifts. With their ability to survive in their homelands thus endangered, the masses have swarmed to the city of Los Angeles' beacon..$^{49}$ But unlike their gentrifying counterparts, L.A. has engaged in a strategy of deflection towards immigrant communities. During Richard Riordan's mayorship, in the 1990s, Los Angeles witnessed significant growth in slums, sweatshops, and overcrowding. Riordan's administration sought to curb the presence of these unsightly reminders of poverty through a "systematic code enforcement program" that supported local municipalities with anti-slum reforms aimed at controlling slum growth and save deteriorating housing values associated with their presence. ${ }^{50}$ He saw his project as humanist; as Riordan stated, "every human being in the city has the right to live in quality housing." ${ }^{1}$ Ivan Light argues these policies received wide support, including from "trade unions, churches, immigrant defense organizations, assorted left-wingers, and even metropolitan business elites [that] rejected the increasing economic inequality that immigration had produced." 52 However, the anti-slum reforms simply reduced the presence of the city's slums, but without a coinciding increase in the affordable housing that "quality housing" presumably entails. On one hand, Los Angeles may currently be representing itself as the flexible city, a city capable of absorbing waves of migration while celebrating its multicultural identity. On the other, the economic realities have been far more ominous for immigrant communities where many must eke out a living in the informal economy, and in a city that would rather their presence be unseen.

Forced to dwell in the shadows of a city unwilling to invest in affordable housing, theirs is an existence that unfolds in the shadows of the neoliberal discourses of individualism, entrepreneurship, and self-reliance. Immigrants must contend with the consequences of the political economy of neoliberal globalization in which precarity has been naturalized while violence increasingly concentrates and intensifies in the poorest neighborhoods. ${ }^{54}$ Furthermore, they must find dwelling in a city whose political system invests millions for the comfort of the creative class while employing harsh anti-slum enforcement policies to push out any sign of the unwanted immigrant presence-or more appropriately, any presence that brings the failures of neoliberalism into relief.

Journal of French and Francophone Philosophy | Revue de la philosophie française et de langue française Vol XXV, No 1 (2017) | http://www.jffp.org | DOI 10.5195/jffp.2017.814 
It is from these immigrant communities from which many of Los Angeles' gangs have historically emerged. Of course, gang formation from marginalized and precarious immigrant communities is nothing new. There are strikingly similar historical parallels between the processes which pushed Black people from the Jim Crow South to Los Angeles, during the Great Migration, and the more recent waves of Central American immigration. The limited economic opportunities associated with the post-Reconstruction south, along with intense anti-black racism, shaped many of the experiences of those who chose to make the urban city their home. Still, for many who settled in Los Angeles, during the Great Migration, were unable to escape many of the socioeconomic perils they faced in the South. The politics of race and class would ultimately force most Black people, and people of color, to live in overcrowded housing and slum conditions. Slums grew rapidly, largely in response to white hostilities to the influx of non-whites into the city. Public housing was considered a panacea but quickly became synonymous with black housing. Given the overt anti-black racism of mid-20 $0^{\text {th }}$ century Los Angeles society, efforts to build affordable housing to alleviate slums became fraught with racial politics. ${ }^{55}$ Like the later waves of Central American immigrants, Los Angeles's Black communities clustered in ways that limited political participation, stunted economic growth, and aided social control (e.g. policing) strategies. The city, shaped by ideologies of white supremacy, systematically contested and denied Black peoples' ability to build communities (physical or otherwise) in a manner facilitating dwelling, that would amount to anything akin to their white counterparts. Ultimately, "the negro" stood out as the urban problem of the $20^{\text {th }}$ century.

At the same time, social organizations antagonistic to the state were forming in these communities. And with the crippling of state welfare programs and the demise of manufacturing sectors, beginning in the 1970s, many of the organizations that initially had political agendas began to change character. They expanded rapidly through networks in the informal economy to gain access to monies denied to them in the formal sectors, while forming rigid social structures to survive within the interstitial spaces of the city's security apparatus. Eventually, we would begin to refer to these organizations as gangs.

By the 1980s, the former governor of California, Ronald Reagan, had reached the White House. There he sought to secure the neoliberal agenda that, in the Latin American arena, saw the support of dictators, drug kingpins, and outright economic dispossession in the name of market liberalization. Halting the expansion of Soviet communism was a politically effective justification that shielded the Reagan administration from any significant reprisals for funding coups, guerrilla armies, and strong-arm dictators. At the same time, at home, Reagan continued and intensified Nixon's "war on drugs" by labeling drug-abuse a national security threat. In contradiction, the C.I.A. used the informal economy of illicit drugs to funnel monies to support

Journal of French and Francophone Philosophy | Revue de la philosophie française et de langue française Vol XXV, No 1 (2017) | http://www.jffp.org | DOI 10.5195/jffp.2017.814 
anti-communists militias, and thus indirectly the neoliberal agenda of Reagan's administration. ${ }^{56}$ The subsequent socio-political upheavals of these processes still reverberate today and inform much of the immigration from Central America to the U.S. For Los Angeles, this meant money, illicit drugs, and immigrants began to flood into a city already rife with chronic poverty and gangs.

This is the Los Angeles confronted by those who eventually became the MS-13. A city shaped by histories of racism, impoverishment, and mass migrations that have repeatedly been addressed by investments in deflective political strategies, increases in policing budgets, and disregard for public housing. "In cities like Los Angeles, on the bad edge of postmodernity," Mike Davis notes, "one observes an unprecedented tendency to merge urban design, architecture and the police apparatus into a single, comprehensive security effort." ${ }^{57}$ Though we may also say some must make a living while residing in a city that actively disregards their dwelling; they are in a sense deeply homeless. That is to say, what immigrants have faced in Los Angeles is both physical homelessness, but also a discursive homelessness in which the ease and comfort associated with dwelling is not prioritized politically nor is economically feasible. Moreover, once an immigrant becomes gangaffiliated, whether by their own doing or labeled so by the judicial system, they must engage state institutions that actively further their homelessness. To think of dwelling in the case of L.A.'s gangs is even further difficult because one confronts state ideologies that mask the problems of housing, jobs, and social institutions through the deviatization and criminalization of those most associated with the physical violence that characterizes crime in poor neighborhoods. What I want to consider then is this ontological homelessness, especially the peculiarity of homelessness when thinking about gangs-those inhumans.

\section{Homelessness: Gang graffiti within L.A.'s securityscape}

What does it mean for a gang to attempt installing themselves as dwellers, especially given the many legitimized forms of surveillance, criminalization, and penalization aimed at denying them such comfort? In this section, I focus on how the enhanced penalization for gang graffiti is one aspect of a larger assemblage of forces that articulate and legitimize state power through enforcing the non-dwelling of gang members. To do so, I will take another further discuss Heidegger's notion of dwelling-as-building to draw out the ways in which it is interrelated with the activity of gathering.

Dwelling is, for Heidegger, intimately interwoven with the question of Being, or what he referred to as the thrownness of a human subject into the world. We can say that we are human precisely because we dwell in the world. By positing dwelling as the primary instance of thinking, Heidegger pushes us to take on what Ingold calls a "dwelling perspective" that he

Journal of French and Francophone Philosophy | Revue de la philosophie française et de langue française Vol XXV, No 1 (2017) | http://www.jffp.org | DOI 10.5195/jffp.2017.814 
defines as "the forms that people build, whether in the imagination or on the ground, [which] arise within the current of their involved activity, in the specific relational context of their practical engagement with their surroundings." 60 From a "dwelling perspective" the concern is not necessarily with how we build at a certain locale, but rather how that locale is elicited by a gathering of human activity. It is more common to think of dwelling-asbuilding in the sense of a brick-and-mortar house that affords family a pleasant and comfortable place to dwell, but less obvious is the dwelling already gathered in its forming. For instance, we might ask then, how is it that architects instill a sense of house-as-dwelling into their designs and from what premise do they do so? Was the blueprint drafted on flat white paper in which they disregarded for the topography of the site? And what kind of family activity was envisioned to be cultivated by the house? We may even approach this as a question of political economy: how does the activity of the urban planner, who may promote the construction of model housing in suburban sites, participate in the unfolding of suburban sprawl? And in what ways did model housing seek to capture a certain concept of human freedom, individualism, and comfort? In this way, a "dwelling perspective" allows us to decenter a certain conception of humanity, so that we may begin asking what concept of humanity is embedded in our building, but also as to what political and economic investments capture certain forms of building-asdwelling.

However, gangs exist in a peculiar relationship to dwelling. The essence of their being, or in other words how they stick out, is intimately attached to the immorality associated with gang activity. This means to dwell as a gang is oxymoronic to the state's sensibilities. The state's investment in their eradication begins, I contend, with their ontological homelessness. There are no architects or urban planners out there designing with gangs in mind.

Let us imagine the MS-13's opening, or clearing, as the barrio of PicoUnion, the district just west of downtown Los Angeles. Not specifically the houses in which these Salvadoreño youth live, and not necessarily the streets of the barrio, but rather the territorializing activity of those locales: the parks, back alleys, and storefronts where they spend their time socializing and conducting illicit business. All those locales in which they traverse and hangout for much of their young lives, those everyday coordinates in which MS-13 youth gather and locate their daily activity and their lives in general. If we take this clearing as territorialization, then we can conceive of the MS-13 as a territorializing social organization engaged in making claims to and transfigurations of their barrio's built environment. In other words, the MS-13 give social form to territoriality and built environment. Gangs can, then, be considered in terms of social activity vacillating between organizing and territorializing with the aim of building-as-dwelling.

Their activity does not happen in a vacuum but within the specific context of their neighborhoods. Their neighborhood is one crisscrossed by

Journal of French and Francophone Philosophy | Revue de la philosophie française et de langue française

Vol XXV, No 1 (2017) | http://www.jffp.org | DOI 10.5195/jffp.2017.814 
processes of criminalization-including police patrols, SWAT raids, gang injunctions, enhanced sentencing, media narratives, housing policies - that extend out from an assemblage of state power-including its judicial system, policing structures, popular narratives, and legislative schemes - which has a central focus the foreclosure of gang (organizing and territorializing) activity. Together these processes form a robust security apparatus where the nondwelling of gangs is integral to the state's maintenance of the threshold between citizen and criminal. Thus, the MS-13 are included in the state's security apparatus but excluded from citizenship belonging through felony or immigration status. This conflict, I suggest, is visible even between the most mundane gang activity and state power, which the presence of gang graffiti brings into relief.

In the 1990s, it was not uncommon to see gang graffiti littering the concrete walls around Pico-Union. Graffiti existed in all forms, from tags and bombs thrown up by rebellious youth to the more utilitarian gang signs used to establish territory. There was among the gang graffiti a plethora of signifying in the form of roll-calls, gang insignias, and so on. They functioned as complex ideographs that etched MS-13 territoriality onto the streets. Through symbolism and its material application, the MS-13 were installing themselves into the streets of Pico Union. The graffiti provided coordinates for the MS-13 on multiple levels, including the marking of territorial boundaries in which the MS-13 can gather and locate their dwelling. As well, it marked their presence, a presence which brought them to the attention of police agencies charged with maintaining social control.

In California law, a distinction is made between misdemeanor graffiti and gang graffiti, a felony. The LAPD explains "why gang graffiti is dangerous" on its website, stating that "of greater concern is the inherent violence associated with gang graffiti... [which indicates] territorial dominance, [and that] the entire area and its inhabitants [will] become targets for violence." 61 Through a variety of tactics of police patrol and camera surveillance, gang graffiti is targeted by Los Angeles' security apparatus and its strategies for state control. Information databases are needed to store visual documentation of gang graffiti and its GPS coordinates, while servers and high-speed processors allow these images to recalled by the police during routine traffic stops. These documents are sites where strategies of surveillance extend themselves through the deciphering and tracking of ideographic symbols, while researchers produce ever sophisticated analytical tools to locate graffiti hotspots and enhance ID matching. ${ }^{62}$ The mundane activity of documenting gang graffiti is then a productive site for the city's security apparatus.

Graffiti abatement legislation, while a seemingly innocuous component of the overall security apparatus, highlights the importance of gang deterritorialization to state power. Legislation defines gang graffiti as more than simply vandalism. Gang graffiti, according to the state, indicates the

Journal of French and Francophone Philosophy | Revue de la philosophie française et de langue française Vol XXV, No 1 (2017) | http://www.jffp.org | DOI 10.5195/jffp.2017.814 
presence of a dwelling inhuman who must be scrutinized and, ideally, eradicated. The inclusion of gang graffiti within the gang-enhancement legislation that includes murder, racketeering, and drug trafficking is a clue as to the value state power places on cultivating the dwelling-as-building of those deemed to matter, and why invests heavily in the non-dwelling of those who do not matter. The ontology of neoliberal ontology-according to which life, liberty, and the pursuit of happiness is tied to private property, air conditioning, and green lawns - compels state intervention, especially when internal enemies lay visible claim to dwelling within it. The state articulates its territorializing activity through legislation, like graffiti abatement programs and gang enhancements, hinging on the maintaining the threshold between city dwellers and gang non-dwellers. Gang-related legislation gives no thought to the ability of gang members to dwell in their neighborhoodsnor does the state believe it should. We can begin to see how the MS-13 are rendered radically homeless, by law. With this in mind, what then can we say about a gang formation that is now remarkably transnational?

\section{The Transnationalization of MS-13}

The 1980s was a period of revolutionary upheaval in El Salvador. The decadelong internecine warfare between the Frente Farabundo Martí para la Liberación Nacional (FMLN) guerrillas and the US-backed Salvadoran state military in many ways decimated the country's social fabric. A combination of land reform, violent military tactics (by both FMLN and the state), and an array of human rights violations were factors in pushing peasants from the countryside into local cities, refugee camps, and eventually to the US. ${ }^{63} \mathrm{With}$ the striking of a truce in 1992, battles once fought between military factions were not shifted to the political arena, where the FMLN fought for political control against the newly formed Alianza Republicana Nacionalista (ARENA). The massive population displacements that characterized the previous decade came to a lull. However, by the 2010s, another mass out-migration to the US began in earnest. This time in large response to the economic perils caused by international trading pacts that left El Salvador at the bottom end of global trade. In the US, media narratives render these narratives of these immigrants legible on terms of human rights and humanitarian crisis, as witnessed recently in stories surrounding the many children stranded at the US/Mexico border by scared and destitute parents. What is not accounted for in these narratives, however, are processes of US deportation policies that have been systematically exporting gang affiliates back to their supposed homelands in Central America. Policies which have only exacerbated the new internecine warfare between gangs, like MS-13 and Barrio 18, and the El Salvadoran state. However, unlike the guerilla armies, these organizations do not speak in terms of vanguardism or radical leftist politics, but rather, in many ways, skirt questions of politics, at least on respectable terms. Maras, as they are referred to in Central America, 64 are considered apolitical social

Journal of French and Francophone Philosophy | Revue de la philosophie française et de langue française Vol XXV, No 1 (2017) | http://www.jffp.org | DOI 10.5195/jffp.2017.814 
formations. They are feared for their violent tactics, and seemingly nihilistic, almost absent, purpose-or at least this is how they have been popularly constructed. Birthed on the streets of L.A., the MS-13 now exist as a transnational social, economic, and political problem, yet not one entirely of their own doing.

Pico-Union was a central destination for Salvadorans fleeing the 1980s civil war. They settled into a neighborhood whose predominant population at the time was $2^{\text {nd }}$ - and $3^{\text {rd }}$-generation Mexicans. The Reagan administration's refusal to admit their refugee status forced them to live clandestine lives of the undocumented. Many Salvadoran you found themselves in neighborhoods "sprawling with crime and gangs, these families not only struggled to overcome the trauma of the war but also faced culture shock, language barriers, discrimination, crowded living conditions and underpaid jobs." 65 With the parallel militarization of law enforcement and anti-dwelling housing policies, the warfare they had fled from in El Salvador was some ways relieved in Los Angeles, but with the added complications of police militarization and anti-dwelling housing and immigration policies. According to most accounts, the MS-13 formed to help young Salvadorans navigate the complexities of gang affiliation and territoriality that had already characterized how human activity responded to these processes on the ground. Though, their pursuit of dwelling in the mode of la vida loca only justified the security apparatus that sought their non-dwelling.

Eventually, the US would begin to adopt deportation policies that sought to exile problematic immigrants. In 1988, the "Drug Kingpin Act" was passed with the intent of addressing gang-like activity. One of its amendments also included provisions for the deportation of noncitizens convicted of an aggravated felony, a category which has expanded significantly since the initial language was ratified. ${ }^{66}$ With legislation in California classifying gang affiliation felonious, the deportation strategies used against the MS-13 members was made strikingly easy.

Their dwelling was further assailed by the abundance of law enforcement agencies funded with the specific intent of targeting MS-13 and other gang formations. This includes agencies like LAPD's Gang and Narcotics/Homicide Division, the INS's Violent Gang Task Force, and the FBI's MS-13 National Gang Task Force. Anthropologist Elana Zilberg has documented how California's targeting of active gang members actually stymied the efforts of Homies Unidos, ${ }^{67}$ a gang intervention organized by former MS-13 members, designed to help quell neighborhood violence. ${ }^{68}$ However, members of Homies Unidos were targeted by police, prevented from standing on street corners for any length of time or conduct meetings without police efforts to infiltrate or spy on them. Zilberg describes how members were often harassed with arrests and tickets for petty crimes. While those unlucky enough to be detained without papers were sent to privatized prisons or deportation camps owned by transnational corporations.

Journal of French and Francophone Philosophy | Revue de la philosophie française et de langue française Vol XXV, No 1 (2017) | http://www.jffp.org | DOI 10.5195/jffp.2017.814 
Eventually they found themselves back in El Salvador, their supposed homelands, ostensibly to rebuild their lives. For almost twenty years this remained the standard practice for anti-gang efforts against undocumented or unnaturalized MS-13.

Deported MS-13 encountered an El Salvador undergoing profound socioeconomic adjustments associated with neoliberalism. Under ARENA's twenty-year reign, El Salvador has slowly privatized its service, telecommunication, and banking sectors, while opening its markets to investments from transnational corporations. ${ }^{69}$ Agricultural exports, mainly coffee and sugar, had dwindled, while service industries had grown exponentially. The service sector alone accounts for $60 \%$ of El Salvador's GNP, a figure mostly fueled by $\$ 4$ billion in remittances from family members in the US. $^{70}$ As in Los Angeles, the entanglement between poverty and dispossession, characteristic of these socioeconomic transformations, was met with the harsh criminalization of the surplus populations caused by transformations in the economy. There was also a similar move to militarize the police and create specialized anti-gang initiatives. In 2003, the government under Antonio Saca began to implement mano dura policies, which legalized paramilitary police units and legitimized massive gang sweeps through the slums of El Salvador that captured anyone visibly gang-affiliated (e.g., had tattoos). ${ }^{71}$ Although these laws have been struck down on constitutional grounds, they nevertheless are evocative of how US-style security apparatus have traversed the name circuits of population and capital migration, laid down by turns in neoliberal globalization.

From a dwelling perspective, we must take seriously the striking similarities between the experiences of MS-13 in both L.A. and El Salvador. How it is that gang activity in the tin-sided shanty walls and concrete rubble of San Salvador's slums, in which graffiti sharing familiar MS-13 coordinates, speaks to historical and spatial interconnections between the political economy, but also to the expressions and search for dwelling. ${ }^{72}$ By force, many MS-13 have had to seek a building-as-dwelling in San Salvador's slums, and they have done so with the risk of death, at the hands of established rival gangs and even state police. ${ }^{73}$ Strangers in the land of their birth, they quickly found themselves targeted by another state hell-bent on their eradication, but this time without a convenient deportation outlet. The internecine warfare that has erupted does not elicit the same kind of concern that civil wars do, because we simply find it difficult to read these events as political, in respectable terms at least. Though, I believe this difficulty is also connected to the inhumanity associated with gangs, which has left them radically left from our thoughts concerning civil politics and economy. Their existence ontologically challenges us. 


\section{Radical Homelessness: Non-dwelling in Fukunaga's Sin Nombre}

Cary Joji Fukunaga's 2009 film Sin Nombre follows a young woman attempting to make her way North through Mexico's tangled and dangerous railway system. The unnamed young woman at the center of the action has joined her father and uncle, who are attempting to cross the border illegally and eventually meet family in New Jersey. They are freight-hopping, huddling on top of a railroad car. The plot turns on a chance encounter between her family and Casper. He is accompanied by one of the leaders of his MS-13 clique, as well by his young friend who had just been initiated. They are on the train to rob the immigrant families carrying monies they hope will buy them passage cross the border. We watch as they lift the covers, used by immigrants to shield themselves from the rain, then shoving a gun in their faces demanding money. However, when they reach our young woman the leader changes when he notices her beauty. When he begins to unbutton his pants, Casper is troubled unable to simply watch as he will try to rape the young woman. Casper lifts his gun and shoots the man before he could assault the young woman. He looks up with the uncanny awe of a person whose world has shifted ground. The rest of the film we follow as Casper as he traverses the gauntlet of railroad agents, corrupt police, and the MS-13's relentless pursuit of their former member.

Only in the film's final scene, as the young woman phones her new family, outside an American mall, do we learn that her name is Sayra. By this point in the film, we share Sayra's memories of loss, separation, anxiety, and dread. Along the way she would lose her father, become estranged from her brother and watch Casper die at the hands of the young boy who watch as he killed a fellow MS-13, for the sake of Sayra. We also share Sayra's uncertainty, as she exchanges greetings with cheerful voices from a family she has never really known.

Sayra's story exemplifies the postglobal subject, embodying the saturation of affective, structural, and social violence resulting from international trade pacts (e.g., NAFTA) that have deterritorialized national economies and facilitated the rise of supranational corporate entities. Sayra's story is but one of untold millions of postglobal subjects caught in the web of globalization's sweeping gale. The scene captures the ineffable experiences of postglobal subjects, "those who have experienced globalization from the bottom...people far removed from the machinations of power and wealth, people whose lives are shaped by the policies of world organizations but have no chance at all to respond and be heard."74 But it is the figure of Casper that best elucidates central questions of the postglobal that remain to be fully explored: What does it mean to face a world not designed for you, one that increasingly lacks the capability to absorb your energies?

And, can one dwell in such a world?

Journal of French and Francophone Philosophy | Revue de la philosophie française et de langue française Vol XXV, No 1 (2017) | http://www.jffp.org | DOI 10.5195/jffp.2017.814 
While Heidegger was concerned with dwelling in its potentiality, we face the story of those "sin nombre," postglobal subjects marked by a fraught existence in which their dwelling is either disregarded or foreclosed. According to Heidegger, the manner in which humans come to understand themselves as being-in-the-world, possessing some essential quality that separates humans from other beings, points to the manner of their dwelling. Building-as-dwelling is an unfolding process, a becoming into being. Sayra and Casper offer a peculiar variation within this existential manifold. In that their existence is grounded in their ambiguous, even tenuous, embeddedness in their environments. Their being-in-the-world is surrounded by the "politics of death," 75 rendering their futures chronically uncertain. Theirs is a story of the entanglement between socioeconomic uprootedness and displacement caused by the deterritorialization of local political economies and reterritorialization of neoliberal globalization. It is not the march towards death or being-toward-death as Heidegger would say, that is at issue, but rather their march in-death that they must face as an everyday reality. This remains true whether they choose to stay in Honduras or risk the journey to a new life in the US. It is their denial of death, in the name of building (a new life), that makes dwelling still possible.

In Sin nombre, we are confronted with the narratives of non-dwelling that characterizes post-globality. The protagonists illicitly ride the northbound trains, holding precariously onto railings designed for railroad workers to inspect or unhook cargo. Along the way they are pelted by rocks from 'innocent' children, cheerfully expressing their distaste for the migrants and their unwillingness to offer hospitality. The migrants later disembark in neighborhoods where music thumps loudly amid graffiti-covered walls, reminding them that they are in the city's interstices where safety is not guaranteed. This manner of movement is a far cry from the secure and comfortable confines of air travel, as experienced by tourists, businesspeople, and other global citizens.

Though in the first dialogue exchange of the film we get a sense Ca'per's non-dwelling is distinct from Sayra's. After the opening scene, in which staring fondly at a poster depicting the serenity of yellow foliage, he runs out into his world which is full of the chaos, noise, and bustle of any urban slum. He is headed to pick up his young friend Benito, the kid who would eventually take his life. However, he arrives at Benito's place, Casper is confronted by the boy's grandmother at the front porch. She angrily attempts to stop Casper from leaving with Smiley. Calling him "un delinquente," she demands that Casper leave, or as she says, "o te mando la policía que te lleve y te encierre, cabron! Este es lo que tu quieres de verdad!? ["or I'll send for the police to get you and lock you up, asshole! That's what you want right!?"]. Her language points to a discursive formation in which Casper's gang affiliation, marked on his body by the numberous tattoos of MS-13 insignia, evokes dread and disgust. All though her attempts at shaming Casper on the

Journal of French and Francophone Philosophy | Revue de la philosophie française et de langue française Vol XXV, No 1 (2017) | http://www.jffp.org | DOI 10.5195/jffp.2017.814 
grounds of gang affiliation rang hollow to him, it nevertheless speaks to how an existence as gang is shaped by its exclusion from society. He should be ashamed, it reads because he is inhuman.

Although "gang" does not stand-alone in this regard, it is prefigured by other formulations by which an entire history of such constructs - the "born criminal," the "outlaw," the "rebel," even Marx's "lumpen" - are deployed to explain criminal actions as the result of underlying criminality embedded in the very flesh of their being. Thus, the figuration of gang and its many variations has, I contended, facilitated the paring away of the ostensibly unsavory elements of society in the same of securing humanity. It is, in short, a discursive strategy that, whatever its particular manifestations, seeks to legislate who gets to dwell, and who must seek refuge somewhere, anywhere, else on earth. They are homeless. Though radically so since their ability to dwell unsettles our humanist philosophies. What I have sought to sketch out above is simply how the non-dwelling of gang has gone unquestioned. To be ashamed simply for existing as something renders such radical homelessness visible. Post-globality provides a framework for bringing these narratives of invisibility to the fore in the discussions of political economy. Although I push us to do so with an awareness of the moral economy that informs our humanist project, in doing so.

\section{Post-global subjects: Mara Salvatrucha 13}

The MS-13 are radically homeless postglobal subjects, whose non-dwelling has been left radically unthought. Alfred López notes that employing the "'post- always brings with it a displacement of actuality" from which a critical distance is brought to bear on the global. ${ }^{80}$ What postglobal denotes is neither here nor there, in the past or future. It does not simply name globalization's failures or accomplishments; it is not its historical record, nor a vestigial remnant. The postglobal it seems affords us a legible rubric for reconsidering the existence of those whose mere existence is a critique from the underbelly of globalization's neoliberal dreamscape.

From this vantage, I am suggesting gang members, once inscribed as such, must contend with the world that articulates itself by, as Agamben might say, through the inclusion of their exclusion. In Heideggerian terms, they are denied dwelling not simply as a concrete reality (e.g., behind bars), but also in a deeply metaphysical sense. If, as Heidegger posits, "the manner in which we humans are on the earth, is baun, dwelling... To dwell, to be set at peace, means to remain at peace within...the free sphere that safeguards each thing in its essence," 81 Then not only are gang members, alongside other precarious lives without a place within the political economy, but gangs, and other inhumans, are specifically denied a place in the deep undercurrents of our thinking, in the humanity we assume in our languaging. Their figuration is a productive site where state power and Western metaphysics converge.

Journal of French and Francophone Philosophy | Revue de la philosophie française et de langue française Vol XXV, No 1 (2017) | http://www.jffp.org | DOI 10.5195/jffp.2017.814 
They do not ostensibly reside in (the ousia of) humanity, at least not the humanity state apparatuses and social institutions seek to celebrate, rescue, or sustain. If we are hones with ourselves, can we think of instances in which the humanity of gangs are considered politically? Why do we not give credence to their territorializing claims? In some sense, these questions are absolutely absurd. Gangs are, in this sense, radically homeless, because their homelessness is both actively sought and given no worry. Can there be a humanitarian project that can face the ontological inhuman? We may even begin to ponder this situation as ontological violence.

${ }^{1}$ Cal. Pen. Code § 186.22.b (2016).

${ }^{2}$ Michael Hardt and Antonio Negri, Empire (Cambridge: Harvard University Press, 2001), 25.

${ }^{3}$ Aihwa Ong, Neoliberalism as exception: Mutations in citizenship and sovereignty, (Raleigh, NC: Duke University Press, 2006), 92.

${ }^{4}$ Cal. Pen. Code Code $\S 186.21$ (West 2008).

${ }^{5}$ Martin Baker, "Crips and Nuns Defining Gang-Related Crime in California under the Street Terrorism Enforcement and Prevention Act," McGeorge Law Review 40 (2009): 892.

${ }^{6}$ Loïc Wacquant, "Crafting the Neoliberal State: Workfare, Prisonfare, and Social Insecurity." Sociological Forum 25, no. 2 (2010): 201.

${ }^{11}$ See Kelly Padgett Lineberger, "The United States-El Salvador Extradition Treaty: A dated obstacle in the transnational war against Mara Salvatrucha (MS-13)," Vanderbbilt Journal of Transnational Law 44 (2011).

13 Alfred J. López, "'Everybody else just living their lives’: 9/11, Race and the New Postglobal Literature." Patterns of Prejudice 42, no. 4-5 (2008): 511.

${ }^{18}$ Stuart Hall, Policing the Crisis: Mugging, The State, and Law and Order (New York: Palgrave Macmillan, 1982), 226.

${ }^{20}$ Nicholas Thoburn, "Difference in Marx: the Lumpenproletariat and the Proletarian Unnamable," Economy and Society 31, no. 3 (2002): 445.

${ }^{21}$ Gustave Le Bon, The Crowd: A Study of the Popular Mind (Mineola: Dover Publications, 2002), 54.

${ }^{22}$ Marx, Karl, and Friedrich Engels. Marx \& Engels Collected Works, Vol. 11 (London: Lawrence \& Wishart, 2015), 149.

${ }^{23}$ William Shakespeare, King Lear II.ii.1086-1095.

${ }^{24}$ Karl Marx and Friedrich Engels. Marx \& Engels Collected Works, Vol. 28 (London: Lawrence \& Wishart, 2015), 203.

${ }^{25}$ Karl Marx, Capital: A Critique of Political Economy, trans. Ben Fowkes (New York: Vintage Books, 1977), 797.

Journal of French and Francophone Philosophy | Revue de la philosophie française et de langue française Vol XXV, No 1 (2017) | http://www.jffp.org | DOI 10.5195/jffp.2017.814 
${ }^{26}$ Hobsbawm's Primitive Rebels sought to historicize this aspect of Marx's thinking. He argues that there exists historical evidence confirming the tendency of 'robin hood' like figures to emerge among the lower classes, only to link up with conservative elements of the political terrain.

${ }^{27}$ He once wrote, the "criminal produces crime...not only crime but the criminal law...the whole of the police and of criminal justice” (quoted in Berkowitz 259). Although Berkowitz suggests this was written in jest, as a commentary on the anti-Semitic discourses surrounding the phantasm of Jews and crime (259). Witty or not, this is further evidence Marx was certainly aware of the workings of the justice system and existence of the criminal element in capitalist society.

${ }^{29}$ Judith R. Walkowitz, Prostitution and Victorian Society: Women, Class, and the State, (Cambridge: Cambridge University Press, 1982), 205.

${ }^{31}$ See Saskia Sassen, The Global City: New York, London, Tokyo, (Trenton, NJ: Princeton University Press, 2001).

${ }^{32}$ See Edward W. Soja, Postmetropolis: Critical Studies of Cities and Regions (Malden: Blackwell Publishing, 2000).

${ }^{33}$ Mike Davis, City of Quartz: Excavating the Future in Los Angeles (New York: Verso Books, 2006), xi.

${ }^{34}$ Soja, Postmetropolis, 211.

${ }^{35}$ Harvey refers to the spatial ordering of production in which the internal contradictions of capital are both physically fixed into place, which, in turn, provides a spatial resolution for continued capitalist growth. see David Harvey, "The spatial fix-Hegel, von Thunen, and Marx." Antipode 13, no. 3 (1981): 1-12.

${ }^{37}$ Sassen, Global City, 325.

${ }^{39}$ Paul Harrison, "The space between us: opening remarks on the concept of dwelling," Environment and Planning D: Society and Space 25, no. 4 (2007): 628.

${ }^{40}$ Heidegger, Martin. "Letter on "Humanism"." Translated by Frank A. Capuzzi. in Pathmarks, edited by William McNeill, 239-76. (Cambridge: Cambridge University Press, 1998).

${ }^{43}$ City of Los Angeles, "Los Angeles GeoHub," Los Angeles GeoHub, 2016.

${ }^{44}$ See Pharazyn da Silva and Lilia Roldán, "Engaging Communities: Participatory Planning in Los Angeles Neighborhoods," PhD diss. (Massachusetts Institute of Technology, 2014).

45 Jamie Foley, "Discover Los Angeles Launches New Domestic Advertising Campaign and Invites Millennials to 'Get Lost' in Los Angeles Sunsets, Art and Other Moments," Business Wire, March 02, 2016.

${ }^{46}$ Neil Smith, "New Globalism, New Urbanism: Gentrification as Global Urban Strategy," Antipode 34, no. 3 (2002): 437-446.

47 Jamie Peck, "Struggling with the Creative Class." International Journal of Urban and Regional Research 29, no. 4 (2005): 763.

${ }^{48}$ See David Ley, "Artists, Aestheticisation and the Field of Gentrification," Urban Studies 40, no. 12 (2003): 2527-2544. See also Andy C. Pratt, "Creative Cities: The Cultural Industries and the Creative Class," Geografiska Annaler: Series B, Human Geography 90, no. 2 (2008): 107-117.

${ }^{49}$ See Rafael Alarcón, Luis Escala, and Olga Odgers, Making Los Angeles Home: The Integration of Mexican Immigrants in the United States (Univ of California Press, 2016).

${ }^{50}$ Ivan Light, Deflecting Immigration: Networks, Markets, and Regulation in Los Angeles (New York: Russell Sage Foundation, 2006), 79..רe Philosophy | Revue de la philosophie française et de langue française Vol XXV, No 1 (2017) | http://www.jffp.org | DOI 10.5195/jffp.2017.814 
${ }^{51}$ Tobar, Hector. "Riordan Signs Law Cracking Down on Slums." Los Angeles Times (Los Angeles), July $15,1998$.

${ }^{52}$ Light, Deflecting Immigration, 79.

${ }^{54}$ See Caldeira, Teresa P. R. "I Came to Sabotage Your Reasoning!" in Law and Disorder in the Postcolony (Chicago: University of Chicago Press, 2008): 102-149. See also Alejandro Lugo, Fragmented Lives, Assembled Parts: Culture, Capitalism, and Conquest at the US-Mexico Border (Austin, TX: University of Texas Press, 2008).

55 Josh Sides, LA City Limits: African American Los Angeles from the Great Depression to the Present (Berkeley: University of California Press, 2003), 118.

${ }^{56}$ William Blum, Killing Hope: US Military and CIA Interventions since World War II (London: Zed Books, 2003), 7-20.

${ }^{57}$ Davis, City of Quartz, 224.

${ }^{60}$ Tim Ingold, The Perception of the Environment: Essays on Livelihood, Dwelling and Skill (New York: Routledge, 2000), 186.

61 LAPD. "Why Gang Graffiti Is Dangerous." Los Angeles Police Department Online. http://www.lapdonline.org/get_informed/content_basic_view/23471.

${ }^{62}$ Anil K. Jain, Jung-Eun Lee, and Rong Jin, "Graffiti-id: Matching and Retrieval of Graffiti Images." In Proceedings of the First ACM Workshop on Multimedia in Forensics (Association for Computing Machinery, 2009), 1-6.

${ }^{63}$ See Aldo Lauria-Santiago and Leigh Binford, eds, Landscapes of Struggle: Politics, Society, and Community in El Salvador (Pittsburgh: University of Pittsburgh Press, 2004).

${ }^{64}$ Mara derives from marabunta, meaning plague (of ants), havoc, or crowd

${ }^{65}$ Sonja Wolf, "Mara Salvatrucha: The Most Dangerous Street Gang in the Americas?" Latin American Politics and Society 54, no. 1 (2012): 71.

${ }^{66}$ Jennifer M. Chacón, "Whose Community Shield: Examining the Removal of the Criminal Street Gang Member," University of Chicago Legal Forum (2007): 321 n.14.

${ }^{67}$ Elana Zilberg, "Fools banished from the kingdom: Remapping geographies of gang violence between the Americas (Los Angeles and San Salvador)," American Quarterly 56, no. 3 (2004): 770-772.

68 The state has virtually criminalized organizations like Homies Unidos. First, they are refused funding, in accordance with California Pen Code $\$ 13826.6$; their community-based organization is only recognized, as such, if they provide information on gang-related activities by their members, directly to the police. If they do not comply with those guidelines and are convicted of a crime, as a gang member, pursuant to Cal. Pen. Code $\$ 1386.22$, then, in accordance with Cal. Pen. Code $\S 186.30$, they must register with the local chief of police or sheriff. Failing to register results in a misdemeanor charge, pursuant to Cal. Pen. Code $\$ 186.33$, which tacks on an additional 16 months, or 2-3 years of jail time to any subsequent charges a person may receive. This is only one of the many tracks of legislative entrapment district attorneys and police can weave to ensnare people in an endless cycle of indictments and/or incarceration.

${ }^{69}$ Forrest D. Colburn, "The Turnover in El Salvador," Journal of Democracy 20, no. 3 (2009): 143-148.

${ }^{70}$ Ibid., 149.

71 Juan J. Fogelbach, "Mara Salvatrucha (MS-13) and Ley Anti Mara: El Salvador's Struggle to Reclaim Social Order," San Diego International Law Journal 7 (2005): 223 n.22, 245-247.

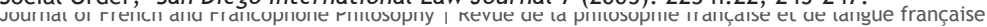
Vol XXV, No 1 (2017) | http://www.jffp.org | DOI 10.5195/jffp.2017.814 
72 See Ellen Moodie, El Salvador in the Aftermath of Peace: Crime, Uncertainty, and the Transition to Democracy (University of Pennsylvania Press, 2011).

${ }^{73}$ See Elana Zilberg, Space of Detention: The Making of a Transnational Gang Crisis between Los Angeles and San Salvador (Raleigh: Duke University Press, 2011).

74 Alfred J. López, "'Everybody else just living their lives’: 9/11, Race and the New Postglobal Literature," Patterns of Prejudice 42, no. 4-5 (2008): 513-514.

75 J.-A. (Achille) Mbembé, "Necropolitics," trans. Libby Meintjes, Public culture 15, no. 1 (2003): 17.

${ }^{80}$ Alfred J. López, "Introduction: The (Post)Global South," The Global South 1, no. 1 (2007): 6.

${ }^{81}$ Heidegger, "Building Dwelling Thinking," 349, 351, emphasis in the original. 